\title{
The variation of bird diversity in various oil palm land cover in North Mamuju, West Sulawesi, Indonesia
}

\author{
SITTI RAMLAH ${ }^{1, \bullet}$, YANTO SANTOSA ${ }^{2}$, NYOTO SANTOSO ${ }^{2}$, SITI BADRIYAH RUSHAYATI ${ }^{4}$ \\ ${ }^{1}$ Program of Conservation, Faculty of Forestry, Universitas Tadulako. Jl. Soekarno-Hatta Km. 9, Mantikulore, Palu 94118, Central Sulawesi, Indonesia. \\ vemail: sittiramlahuntad@gmail.com. \\ ${ }^{2}$ Division of Ecology and Wild Animal Management, Department of Forest Resources Conservation and Ecotourism, Faculty of Forestry and \\ Environment, Institut Pertanian Bogor. Jl. Ulin Lingkar Kampus, Dramaga, Bogor 16680, West Java, Indonesia \\ ${ }^{4}$ Division of City Forest and Environmental Service, Department of Forest Resources Conservation and Ecotourism, Faculty of Forestry and \\ Environment, Institut Pertanian Bogor. Jl. Ulin Lingkar Kampus, Dramaga, Bogor 16680, West Java, Indonesia
}

Manuscript received: 5 May 2021. Revision accepted: 30 June 2021.

\begin{abstract}
Ramlah S, Santosa Y, Santoso N, Rushayati SB. 2021. The variation of bird diversity in various oil palm land cover in North Mamuju, West Sulawesi, Indonesia. Biodiversitas 22: 3068-3074. The development of oil palm plantations provides various positive impacts. On the other hand, this development is suspected to bring negative impacts on biodiversity, especially reducing bird species diversity. Based on the other research, well-managed oil palm plantations that maintain high conservation value areas have high species diversity. This study aimed to identify bird species diversity in different types of oil palm plantation land covers in North Mamuju. Data observation of bird species was performed using the transect method. There were 4 transects on each land cover. The results of this study showed that the young oil palm area had a high index of diversity and species richness. The high species diversity in the young palm area was caused by habitat variations. There was a water flow that provides more feed sources. The distance between the young oil palm area and secondary forest area affected the number of species, species richness and diversity of bird species. The category of insectivore guild which included aerial insectivores and insectivores was the dominant guild in all types of land cover, both in the number of species and the number of individual abundances.
\end{abstract}

Keywords: Bird community, species composition, species richness, species diversity, transect method

\section{INTRODUCTION}

Oil palm plantations are spread across various islands in Indonesia. Obidzinski et al. (2012) and Teuscher et al. (2015) explained that oil palm cultivation in Indonesia increased from 4.2 million ha in 2000 to more than 8 million ha in 2010. Global demand for oil palm was estimated to continuously increase and the most suitable area for oil plantation was tropical forest (Vijay et al. 2016). The development of oil palm plantations was supporting Indonesia's economy and solving the poverty in rural areas (Obidzinski et al. 2012; Teuscher et al. 2015; Kwatrina et al. 2019).

On the other hand, oil palm plantations are also suspected to cause a negative impact on biodiversity, especially decreasing the diversity of bird species. Bird species richness decreased due to land cover conversion into plantations (Ambarli and Bilgin 2013; Subasinghe et al. 2014; Srinivas and Koh 2016; Simamora et al. 2021).

Oil palm plantations that maintain high conservation areas have high species diversity (Meijaard and Sheil 2013; Barnes et al. 2014). Research conducted by Fitzherbert et al. (2008) showed that although initially, oil palm plantation development caused a decrease in bird diversity, later bird diversity increased along with the growth of oil palm plantations. Bird diversity protection in oil palm plantations was essential because insectivorous birds can control insect pests in agriculture (Santosa et al. 2018;
Yudea and Santosa 2019).

Oil palm plantations in Indonesia, usually, are unevenaged and close to secondary forests. The different ages of vegetation affected differences in habitat structure (Palomeque et. al. 2021). Oil palm plantation close to the secondary forest also has different habitat structures. Kiros et al. (2018) explained that the diversity of bird species was influenced by habitat variations.

Based on these arguments, research on diversity in different oil palm land covers is necessary. This study aimed to identify bird species diversity in different types of oil palm plantation land covers in North Mamuju. Information about bird species diversity in the oil palm plantation is required for better management of oil palm plantations.

\section{MATERIALS AND METHODS}

\section{Study area}

The study was conducted at an oil palm plantation in North Mamuju District, West Sulawesi, Indonesia. Observations were carried out at oil palm areas (based on oil palm age: young-aged oil palm (YOP), medium-aged oil palm (MOP), old-aged oil palm (OOP)), High Conservation Value (HCV) area and community garden (CG) area. YOP was a 1-5 years old oil palm, MOP was a 6-10 years old oil palm, and OOP was an oil palm more 
than 10 years old. The HCV area in this research is a secondary forest located on the right and left sides of the Majene River. This area is covered by trees, dry shrubs, understorey and bamboo formations. CG area is smallholding oil palm intercropped with other commercial plants such as citrus, cacao, or coconut. The palm oil in the CG area is 3-13 years old (Figure 1).

\section{Procedures}

\section{Data collection}

Data collection was carried out during May-July 2018 using the transect method on each land cover. Transect lines were 1 kilometer $(\mathrm{km})$ long and 50 meters $(\mathrm{m})$ wide on both sides which repeated 5 times on each land cover type. Observations were performed by 2 people simultaneously on each transect line. The observation was conducted during the bird's active time at 06.00-08.00 AM and 04.00-06.00 PM Central Indonesia Time (WITA). The observation collected data of birds which included species, the number of birds seen, encounter time, bird's activities. The transect was walked one time in each time observation. Observation point and transect illustration are shown in Figure 2.

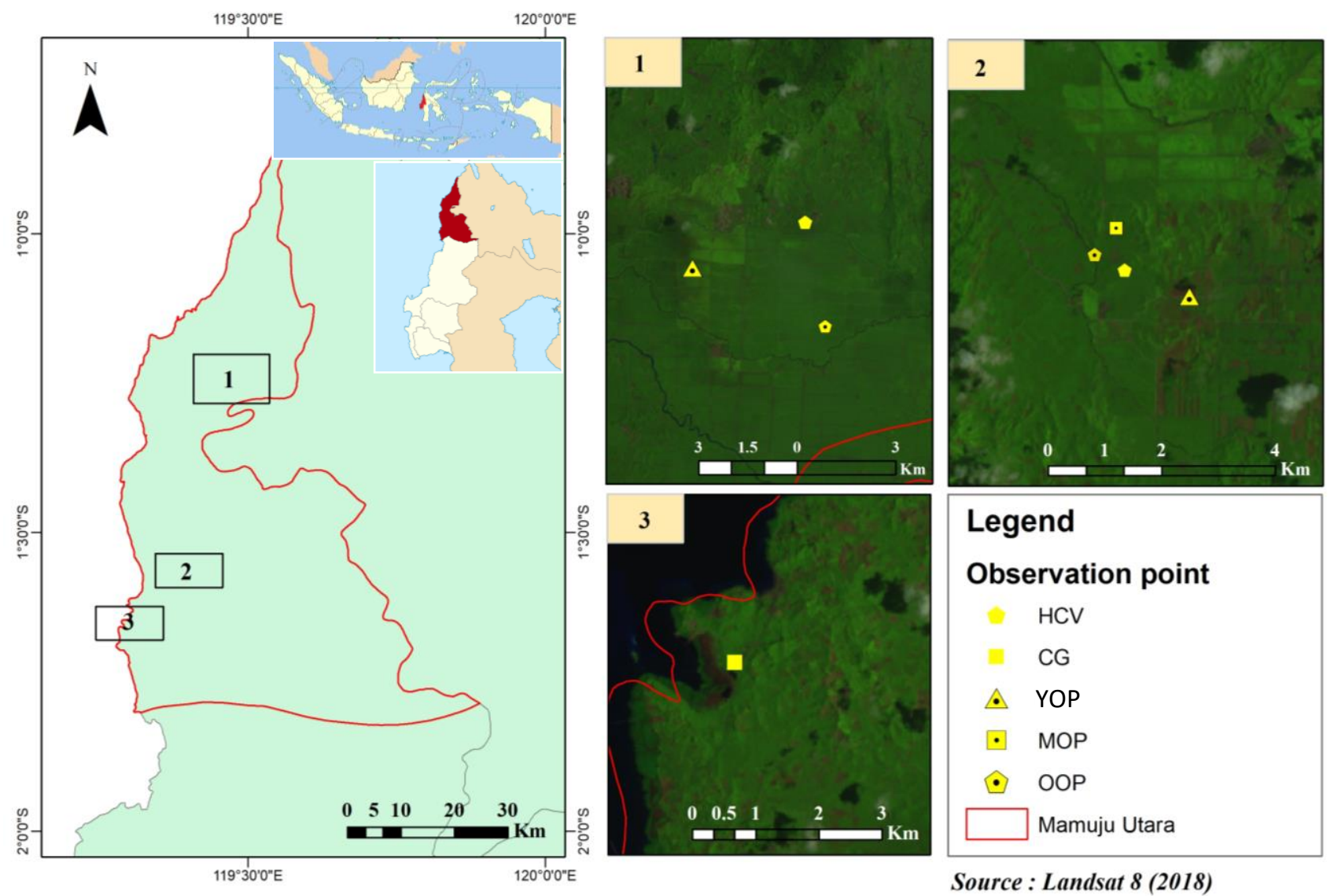

Figure 1. Study location map at oil palm plantations in North Mamuju District, West Sulawesi, Indonesia. Note: YOP: young-aged oil palm; MOP: medium-aged oil palm; OOP: old-aged oil palm

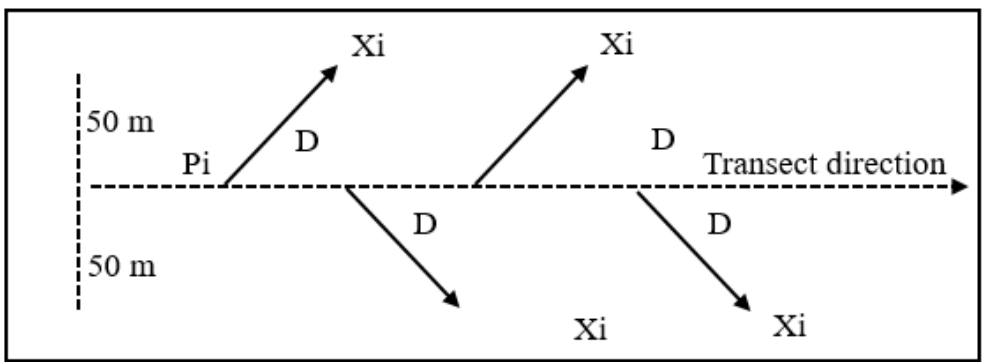

Figure 2. Observation point and transect method illustration. Sample unit for bird wildlife inventory using the line transect method: D: the distance between the observer and wildlife (bird), Xi: Bird location, Pi: Observation point, $25 \mathrm{~m}$ : Observer visibility 


\section{Data analysis}

Species diversity index ( $\left.H^{\prime}\right)$

The bird species diversity was determined using the Shannon diversity index (H') (Ludwig and Reynolds 1988). The index formulation is as follows:

$$
\begin{aligned}
\mathrm{H}^{\prime} & =-\sum_{i=1}^{S}\left(p_{i} \ln p_{i}\right) \\
\mathrm{p}_{\mathrm{i}} & =\frac{\text { Bird species }-\mathrm{i}}{\text { The total number of bird }}
\end{aligned}
$$

\section{Where:}

$\mathrm{H}^{\prime}$ : Diversity Index of Shannon

$\mathrm{S}$ : The number of species

pi : The number of species-i proportion $(n / N)$

Ln : Natural logarithm

\section{Species richness index (Dmg)}

The species richness of birds was determined using the Species Richness index (Magurran 2004). The index formulation is as follows:

$$
\text { Dmg }=\frac{S-1}{\ln (N)}
$$

\section{Where:}

Dmg : Species Richness index

$\mathrm{S}$ : The number of species

ln : Natural logarithm

$\mathrm{N}$ : Total number of species

Species index of evenness $(E)$

The proportion of bird species abundance was calculated using an evenness index (Index of Evenness) (Krebs 1978). The index formulation is as follows:

$$
\mathrm{E}=\frac{H^{\prime}}{\ln S}
$$

$$
\begin{aligned}
& \text { Where: } \\
& \mathrm{E} \quad \text { : Index of Evenness } \\
& \mathrm{S} \quad \text { : The number of species } \\
& \mathrm{ln} \quad \text { : Natural logarithm } \\
& \mathrm{H}, \quad \text { : Diversity Index of Shannon }
\end{aligned}
$$

\section{Similarity index of bird species}

The similarity of bird species in each location was determined with the Jaccard similarity index (Krebs 1978). The index formulation is as follows:

$$
(S j)=\frac{a}{a+b+c}
$$

Where:

a: Number of common species in communities A and B b: Number of species that appeared in community A but did not appear in community B

c: Number of species that appeared in community B but did not appear in community A

\section{RESULTS AND DISCUSSION}

\section{Species composition and bird guild}

The total number of bird species found in the study location was 32 species. These 32 bird species belonged to 18 families (Table 1) and 8 guilds (Table 2). The total number of birds that have been recorded was 449 individuals. YOP land cover type had the highest number of bird species as many as 28 species (87\%) with the number of 100 individuals. In contrast, CG 7 land cover type had the lowest number of bird species as many as 16 species $(50 \%)$ with the number of 42 individuals (Table 1$)$.

Eight bird species were found in all land cover types. These birds were Spilopelia chinensis, Chalcophaps indica, Elanus caeruleus, Todiramphus chloris, Amaurornis phoenicurus, Gallirallus torquatus, Apus apus, and Pycnonotus aurigaster. The bird from Columbidae and Ardeidae families were the most frequently found which consisted of five species and four species, respectively (Table 1). There are 12 families with only 1 species of bird. The Tytonidae family had the lowest number of species and the number of individuals.

This study grouped eight types of bird feed guilds with different species of composition (Table 2). Aerial insectivores and insectivores guilds were the most dominant in the study locations by $34 \%$. Aerial insectivores is predominantly bird feeding on insects in the air, e.g. swifts and swallows and insectivores (terrestrial/arboreal) is predominantly bird feeding on insects, excluding guild aerial insectivore (Kissling et al. 2012). The second-largest guild category was the frugivore at $18.75 \%$. At the same time, the nectarivore guild was the guild with the lowest species composition which was one species (3\%). This species was olive-backed sunbird (Nectarinia jugular) of the family Nectariniidae. This bird was only found in the High Conservation Value (HCV) land cover type. Seven guilds were found in all land cover types from the eight existing guilds. CG 7 land cover type had the lowest guild which was 6 bird feed guilds (Table 2). The number of guilds on each land cover can be seen in Table 2 .

\section{Species composition and bird guild}

Six observation sites in this study have distinguished physical conditions in forming habitats. This is indicated by the diverse composition of families, species, and individual birds found to form communities. The composition of the number of families, the number of species, and the number of individuals in each habitat or location understudy is different (Table 3). Based on the analysis, YOP land cover had the highest Dmg Index, number of bird species (28 species), and Diversity Index $\left(\mathrm{H}^{\prime}\right)$, compared to the other land cover types.

The results of species diversity and evenness index analysis in all land cover types can be seen in Table 3. Although the average results were not significantly different, the highest diversity index was found in the YOP land cover with the highest diversity $\left(\mathrm{H}^{\prime}=2.950\right)$. CG 8 occupied the second-highest diversity $\left(\mathrm{H}^{\prime}=2.874\right)$.

Both CG 8 and CG 7 were community gardens that were planted with citrus and cacao. The CG 8 and CG 7 
land cover types had a similar Index of Evenness, but it relatively high compared to the other land covers (E CG 8 $=0.904$ and $\mathrm{E} C \mathrm{CG} 7=9.150)$. In contrast, the two land cover types had a different total number of individuals $(E$ CG $8=81$ and E CG $7=42$ ) and species diversity (H' CG $8=2.874$ and H' CG $7=2.537$ ) (Table 3).

Species Richness (Dmg) Index is inversely related to Index of Evenness (E). YOP land cover had the highest species diversity and Dmg Index but had an $\mathrm{E}$ index lower than CG 7 land cover. CG 7 land cover had the highest E index second after MOP land cover. Otherwise, mature oil palm plantation (MOP) had the lowest number of species with a Dmg Index of 4.029 (13 species). All can be seen in Table 3.

Both OOP and CG 8 land cover types had 0.92 (92\%) of Similarity Index. Those land covers had the highest Similarity Index, compared to other land covers. 18 species of birds were found at both locations. Otherwise, MOP land cover and HCV area had the lowest Similarity Index which was $0.25(25 \%)$. CG 8, OOP, YOP land cover types had Similarity Index relatively high compared to the other land cover types $(\mathrm{S}>85 \%)$. The similarity Index between land covers can be seen in Table 4.

Table 1. Bird Species Diversity in different oil palm plantation land cover in North Mamuju. YOP: young-aged oil palm, MOP: medium-aged oil palm, OOP: old-aged oil palm, HCV: high conservation value, and CG: community garden

\begin{tabular}{|c|c|c|c|c|c|c|c|c|}
\hline Family & Scientific name & Local name & YOP & MOP & OOP & HCV & CG 7 & CG 8 \\
\hline \multirow[t]{5}{*}{ Columbidae } & Spilopelia chinensis & Spotted dove & 8 & 7 & 12 & 3 & 7 & 8 \\
\hline & Chalcophaps indica & Common emerald dove & 5 & 9 & 13 & 1 & 4 & 2 \\
\hline & Ducula radiata & Grey-headed imperial pigeon & 5 & 0 & 5 & 2 & 1 & 2 \\
\hline & Treron vernans & Pink-necked green pigeon & 2 & 0 & 1 & 2 & 1 & 1 \\
\hline & Ducula aenea & Green imperial pigeon & 0 & 0 & 0 & 2 & 0 & 0 \\
\hline \multirow[t]{4}{*}{ Ardeidae } & Ardeola speciosa & Javan pond heron & 4 & 2 & 2 & 0 & 0 & 2 \\
\hline & Ardea purpurea & Purple heron & 2 & 2 & 2 & 0 & 0 & 1 \\
\hline & Egretta garzetta & Little egret & 1 & 0 & 0 & 1 & 0 & 1 \\
\hline & Ixobrychus cinnamomeus & Cinnamon bittern & 4 & 2 & 0 & 0 & 0 & 0 \\
\hline \multirow[t]{3}{*}{ Accipitridae } & Elanus caeruleus & Black-winged kite & 2 & 1 & 2 & 1 & 1 & 4 \\
\hline & Haliastur indus & Brahminy kite & 1 & 1 & 0 & 0 & 0 & 0 \\
\hline & Circus assimilis & Spotted harrier & 0 & 0 & 0 & 2 & 0 & 0 \\
\hline \multirow[t]{2}{*}{ Alcedinidae } & Todiramphus chloris & Collared kingfisher & 3 & 3 & 10 & 3 & 4 & 5 \\
\hline & Alcedo meninting & Blue-eared kingfisher & 1 & 0 & 1 & 2 & 0 & 1 \\
\hline \multirow[t]{2}{*}{ Hirundinidae } & Hirundo tahitica & Pacific swallow & 15 & 2 & 3 & 0 & 2 & 2 \\
\hline & Hirundo rustica & Barn swallow & 1 & 0 & 0 & 1 & 0 & 0 \\
\hline \multirow[t]{2}{*}{ Rallidae } & Amaurornis phoenicurus & White-breasted waterhen & 8 & 5 & 3 & 3 & 1 & 6 \\
\hline & Gallirallus torquatus & Barred rail & 3 & 5 & 3 & 1 & 2 & 5 \\
\hline \multirow[t]{2}{*}{ Cuculidae } & Eudynamys orientalis & Australian koel & 2 & 0 & 4 & 2 & 2 & 7 \\
\hline & Centropus bengalensis & Lesser coucal & 1 & 2 & 4 & 0 & 1 & 2 \\
\hline Anatidae & Dendrocygna arcuata & Wandering whistling duck & 1 & 2 & 0 & 0 & 0 & 1 \\
\hline Apodidae & Apus apus & Common swifts & 4 & 5 & 5 & 3 & 6 & 9 \\
\hline Campephagidae & Lalage sueurii & White-shouldered triller & 2 & 0 & 5 & 1 & 0 & 1 \\
\hline Corvidae & Corvus enca & Slender-billed crow & 4 & 1 & 1 & 0 & 1 & 1 \\
\hline Dicruridae & Dicrurus hottentottus & Hair-crested drongo & 2 & 0 & 1 & 1 & 2 & 6 \\
\hline Estrildidae & Lonchura malacca & Tricolored munia & 1 & 5 & 0 & 0 & 0 & 0 \\
\hline Nectarinidae & Cinnyris jugularis & Olive-backed sunbird & 0 & 0 & 0 & 12 & 0 & 0 \\
\hline Oriolidae & Oriolus chinensis & Black-naped oriole & 2 & 0 & 2 & 1 & 2 & 1 \\
\hline Pycnonotidae & Pycnonotus aurigaster & Sooty-headed bulbul & 14 & 11 & 3 & 2 & 5 & 9 \\
\hline Sturnidae & Acridotheres javanicus & Javan myna & 1 & 0 & 1 & 1 & 0 & 1 \\
\hline Turnicidae & Turnix suscitator & Barred buttonquail & 1 & 3 & 27 & 0 & 0 & 3 \\
\hline Tytonidae & Tyto alba & Barn owl & 0 & 0 & 0 & 1 & 0 & 0 \\
\hline Total & & & 100 & 68 & 110 & 48 & 42 & 81 \\
\hline
\end{tabular}

Table 2. Guild composition of different oil palm plantation land covers

\begin{tabular}{lccccccc}
\hline \multicolumn{1}{c}{ Guild } & YOP & MOP & OOP & HCV & CG 7 & CG 8 & Total \\
\hline Carnivore & 3 & 3 & 2 & 4 & 2 & 2 & 14 \\
Frugivore & 5 & 2 & 5 & 6 & 5 & 5 & 28 \\
Granivore & 3 & 3 & 2 & 1 & 1 & 2 & 12 \\
Aerial Insectivore & 3 & 2 & 2 & 2 & 2 & 2 & 13 \\
Insectivore & 8 & 3 & 7 & 8 & 5 & 8 & 39 \\
Omnivore & 3 & 3 & 1 & 0 & 1 & 2 & 10 \\
Piscivore & 3 & 2 & 3 & 1 & 0 & 0 & 12 \\
Nectarivore & 0 & 0 & 0 & 1 & 0 & & 1 \\
\hline
\end{tabular}


Table 3. Parameters of bird species diversity in different oil palm land covers

\begin{tabular}{lcccccc}
\hline \multicolumn{1}{c}{ Parameters } & \multicolumn{4}{c}{ Land cover type } \\
\cline { 2 - 7 } & YOP & MOP & OOP & HCV & CG 7 & CG 8 \\
\hline The number of species (S) & 28 & 18 & 22 & 22 & 16 & 24 \\
Total number of individual (N) & 100 & 68 & 110 & 48 & 42 & 81 \\
Species Diversity Index (H') & 2.950 & 2.648 & 2.617 & 2.773 & 2.537 & 2.874 \\
Species Richness Index (Dmg) & 5.860 & 4.029 & 4.468 & 5.425 & 4.013 & 5.234 \\
Index of Evenness (E) & 0.890 & 0.916 & 0.847 & 0.897 & 0.915 \\
\hline
\end{tabular}

Table 4. Similarity indexes of bird communities between land cover types

\begin{tabular}{clllll}
\hline Land cover type & MOP & OOP & HCV & CG 7 & CG 8 \\
\hline YOP & 0.64 & 0.79 & 0.57 & 0.57 & 0.86 \\
MOP & & 0.54 & 0.25 & 0.48 & 0.60 \\
OOP & & & 0.57 & 0.73 & 0.92 \\
HCV & & & & 0.52 & 0.59 \\
CG 7 & & & & & 0.67 \\
\hline
\end{tabular}

\section{Discussion}

The study result showed that YOP land cover had the highest $\mathrm{H}^{\prime}$ Index, Dmg Index, the total number of individuals, and the total number of species. Other studies in Kalimantan and Sumatera also showed that young growth oil palm has the highest species diversity compared to medium and old-growth oil palm (Erniwati and Santosa 2019; Yudea and Santosa 2019). Furthermore, harvesting activities in medium and old-growth oil palm land cover caused undergrowth to be less dense than the young growth oil palm plantation. The area was frequently visited by humans and the environment had a high level of human disturbance. Human activities caused a disturbance that can affect species diversity in their habitat (Azhar et al. 2014).

Eight species of birds occupied six existing land cover types. Spotted doves (Spilopelia chinensis) and Sootyheaded bulbul (Pycnonotus aurigaster) were the most dominant birds among the eight species. Those species were tolerant to human activity.

YOP land cover location was close to the secondary forest area. This land cover type was well managed so that became a more stable habitat and capable of supporting high diversity (Teuscher et al. 2015). The higher the diversity index of an ecosystem, the more stable that ecosystem; and vice versa, the lower the index, the less stable the ecosystem (Kachare et al. 2011). Subasinghe and Sumanapala (2014) explained that the complexity of habitat structure provided greater bird diversity. This result implies that the forest area close to the plantation area is an important habitat that provides abundant food, water, and shelter. The absence of forests might lead to the extinction of birds and other species. This is consistent with another result by Krisanti et al. (2017).

Hair-crested drongo (Dicrurus hottentottus) and blacknaped oriole (Oriolus chinensis) were found both in YOP land cover and secondary forest. The birds are coming from the secondary forest to spend time in the palm oil plantations. Distance between secondary forest and YOP land cover was suspected to give an effect on the YOP land cover bird diversity. Patches of native vegetation within oil palm plantations correlates positively with biodiversity (Koh 2008; Azhar et al. 2013; Gilroy et al. 2015). The diversity of species increases when approaching the source of diversity (Moudry et al. 2021). The patches also can serve as corridors, connecting spatially separated parts of the forest (Edwards et al. 2010). The presence of patches made it easy for birds to fly towards YOP land cover without a major obstacle from their environment.

The distance between secondary forest and oil palm plantation specifically affected the number of species, species richness, and species diversity. MOP and OOP land cover that relatively far to the secondary forest had lower species diversity compared to YOP land cover (Table 3). Species richness and total abundance were negatively associated with distance to forests (Gilroy et al. 2014; López-Ricaurte et al. 2017).

This study result showed that the bird diversity of young-aged oil palm (YOP land cover) was higher than HCV area, other oil palm land cover (MOP and OOP), and community garden (CG). Yudea and Santosa (2019) said that conversion from secondary forest and shrubs into oil palm plantations increased bird number of species and bird species composition. At the same time, the conversion also had an impact on species lost that caused by those species cannot fit in oil palm plantation habitat (Azhar et al. 2013; Srinivas and Koh 2016; Erniwati and Santosa 2019; Yudea and Santosa 2019). Existing oil palm plantations can be made more hospitable to wildlife through various modifications, even the most wildlife-friendly oil palm plantations are a poor habitat compare to forests (Koh 2008; Gilroy et al. 2014; Srinivas and Koh 2016; Kissinger et al. 2017).

The findings were different from some other studies. Azhar et al. (2011) said that secondary forests supported higher species richness and more diverse birds than oil palm landscapes. The study by Erniwati and Santosa (2019), in large palm oil land cover, implied that the lowest number of individuals was on medium-aged palm oil plantations. Santosa et al. (2018) said that the highest species diversity was in oil palm plantation conservation areas and followed by smallholding, old-growth oil palm, young growth oil palm. Gilroy et al. (2014) and Azhar et al. (2014) explained that intercropped palm oil plantations with other commercial plants or trees had more high species diversity compared to monoculture oil palm plantations. The differences in the results studies were caused by variations in feed sources. YOP land cover 
contained streams, which is overgrown with a shrub. Thus, it also explained that the reason eight species of water birds were found in this land cover. The flow of water was used by the family of Ardeidae and Rallidae as a habitat, where streams affect the existence of a piscivore on a habitat type (Issa 2019; Iswandaru et al. 2020).

The flow of water was found in the middle of YOP, OOP, and CG 8. Those land covers had similar habitat conditions. It was suspected to affect the species similarity (>85\%) (Table 4). According to Issa (2019) and Iswandaru et al. (2020), habitat components such as water flow affect the existence of a piscivore guild on a habitat type. Ntongani and Andrew (2013) also explained that the piscivore guild has a dependence on the wetland.

The existing bird species that dominated in this study were tolerant to human activities. Although dominated by the tolerant species, each habitat consisted of different species. This difference was influenced by habitat variations that result in more food sources. Ferger et al. (2014) stated that habitat variation caused variations in the food source. The kind of human activities also caused species variations (Issa 2019).

Feed guild of aerial insectivores and insectivores was the dominant guild in all land cover types, both the number of species and the number of individual abundances (Table 2). Different guilds indicate a preference for different habitats (Ding et al. 2019). HCV area was dominated by insectivores but they were rarely seen in MOP land cover. Insectivores dominated in YOP land cover by $39 \%$, MOP land cover by $28 \%$, OOP land cover by $41 \%, \mathrm{HCV}$ area by $48 \%$, CG 7 land cover by $44 \%$, and CG 8 land cover by $42 \%$. Insectivore domination was due to the availability of feed for the species in the guild category and vegetation structure. Ferger et al. (2014) said that vegetation structure had the strongest overall effect on species richness of insectivorous birds compared to other feed guilds. Suitability of habitat to species of birds found will form a community of birds based on the type of feed guild (Iswandaru et al. 2020).

The opened oil palm plantations brought an abundance of insects. Ghazali et al. (2016) explained that arthropod order richness increased with increasing number of immature oil palms. The availability of insects in a habitat type is more stable than other food sources (Ferger et al. 2014). Insectivorous birds have more feed sources in this research location. Conversely, fruit and nectar are influenced by the time of the fruiting season (Ferger et al. 2014; Mardiastuti et al. 2014). Abundant feed resources increase the bird species of a guild and vice versa. Frugivore birds were relatively more abundant in the CG area (Table 2). CG area or smallholdings typically supported multi-age stands where oil palm plants were intercropped with other commercial plants (Azhar et al. 2013). This condition provided more food and shelter (Subasinghe and Sumanapala 2014).

The nectarivore guild category was a guild that had fewer bird species and it was only found in the HCV area. Whereas nectarivore bird surprisingly was found in oil palm plantation areas (Azhar et al. 2014; Srinivas and Koh 2016). The species was only Cinnyris jugularis. It is implied that in the HCV the area grows the type of flower that becomes the source of feed Cinnyris jugularis (Srinivas and Koh 2016). Nectarivore bird was also found in oil palm HCV area, in South Kalimantan (Kissinger et al. 2017) and secondary forest (Edwards et al. 2013). The more guild categories in a habitat type indicated the abundance of available resources which also showed good environmental quality (Ferger et al. 2014; Ding et al. 2019).

In conclusion, YOP land cover had the highest Diversity and Species Richness Index. Species diversity in YOP land cover was caused by water flow which resulted in more food sources and shelter. YOP land cover also located close to secondary forest. It caused YOP land cover habitat conditions more variable. The more varied the habitat, the more diverse the diversity. The forest area close to the plantation area was an important habitat that provides abundant food, water, and shelter for birds to sustain their life. The aerial insectivores and insectivores were the dominant guild throughout the land cover types, both the number of species and the number of individual abundances.

\section{REFERENCES}

Ambarli D, Bilgin CC. 2013. Effects of landscape, land use, and vegetation on bird community composition and diversity in Inner Anatolian steppes. Agric Ecosyst Environ 182 (1): 37-46. DOI: 10.1016/j.agee.2013.11.006.

Azhar B, Lindenmayer DB, Wood J, Fischer J, Manning A, McElhinny C, Zakaria M. 2011. The conservation value of oil palm plantation estates, smallholdings and logged peat swamp forest for birds. For Ecol Manag 262: 2306-2315. DOI: 10.1016/j.foreco.2011.08.026.

Azhar B, Lindenmayer DB, Wood J, Fischer J, Manning A, McElhinny C, Zakaria M. 2013. The influence of agricultural system, stand structural complexity and landscape context on foraging birds in oil palm landscapes. Ibis 155(2): 297-312. DOI: 10.1111/ibi.12025.

Azhar B, Puan CL, Zakaria M, Hassan N, Arif M. 2014. Effects of monoculture and polyculture practices in oil palm smallholdings on tropical farmland birds. Basic Appl Ecol 15 (4): 336-346. DOI: 10.1016/j.baae.2014.06.001.

Barnes AD, Jochum M, Mumme S, Haneda NF, Farajallah A, Widarto TH, Brose U. 2014. Consequences of tropical land use for multitrophic biodiversity and ecosystem functioning. Nat Commun 5: 1-7. DOI: $10.1038 /$ ncomms6351.

Ding Z, Liang J, Hu Y, Zhou Z, Sun H, Liu L, Liu H, Hu H, Si X. 2019. Different responses of avian feeding guilds to spatial and environmental factors across an elevation gradient in the central Himalaya. Ecol Evol 9 (7): 4116-4128. DOI: 10.1002/ece3.5040.

Edwards DP, Hodgson JA, Hamer KC, Mitchell SL, Ahmad AH, Cornell SJ, Wilcove DS. 2010. Wildlife-friendly oil palm plantations fail to protect biodiversity effectively. Conserv Lett 3: 236-242. DOI: 10.1111/j.1755-263X.2010.00107.x.

Edwards FA, Edwards DP, Hamer KC, Davies RG. 2013. Impacts of logging and conversion of rainforest to oil palm on the functional diversity of birds in Sundaland. Ibis 155 (2): 313-326. DOI: 10.1111/ibi.12027.

Erniwati, Santosa Y. 2019. Loss and gain of the bird species after the establishment of oil palm plantation in South Sumatra. IOP Conf Ser: Earth Environ Sci 336: 012029. DOI: 10.1088/17551315/336/1/012029.

Ferger SW, Schleuning M, Hemp A, Howell KM, Böhning-Gaese K. 2014. Food resources and vegetation structure mediate climatic effects on species richness of birds. Glob Ecol Biogeogr 23: 541-549. DOI: $10.1111 /$ geb.12151.

Fitzherbert EB, Struebig MJ, Morel A, Danielsen F, Brühl CA, Donald PF, Phalan B. 2008. How will oil palm expansion affect biodiversity? Trends Ecol Evol 23 (10): 538-545. DOI: 10.1016/j.tree.2008.06.012. 
Ghazali A, Asmah S, Syaðq M, Yahya MS, Aziz N, Peng T, Norhisham AR, Puan CL, Turner EC, Azhar B. 2016. Effects of monoculture and polyculture farming in oil palm smallholdings on terrestrial arthropod diversity. J Asia-Pac Entomol 19 (2): 415-421. DOI: 10.1016/j.aspen.2016.04.016.

Gilroy JJ, Prescott GW, Cardenas JS, Castañeda PGDP, Sánchez A, Rojas-Murcia LE, Edwards DP. 2014. Minimizing the biodiversity impact of Neotropical oil palm development. Glob Change Biol 21 (4): 1531-1540. DOI: $10.1111 / \mathrm{gcb} .12696$

Issa MAA. 2019. Diversity and abundance of wild birds species' in two different habitats at Sharkia Governorate, Egypt. J Basic Appl Zool 80 (34): 1-7. DOI: 10.1186/s41936-019-0103-5.

Iswandaru D, Novriyanti N, Banuwa IS, Harianto SP. 2020. Distribution of bird communities in University of Lampung, Indonesia. Biodiversitas 21 (6): 2629-2637. DOI: 10.13057/biodiv/d210634.

Kachare VS, Pawar RS, Panaskar DB. 2011. Disturbances on the living of birds and their population in Wetlands of Kolhapur City, Maharashtra (India). Eur J Exp Biol 1 (1): 43-50.

Kiros S, Afework B, Legese KA. 2018. Preliminary study on bird diversity and abundance from Wabe fragmented forests around Gubresubcity and Wolkite town, Southwestern Ethiopia. Int J Avian Wildlife Biol 3 (5): 333-340. DOI: 10.15406/ijawb.2018.03.00116.

Koh LP. 2008. Can oil palm plantations be made more hospitable for forest butterflies and birds? J Appl Ecol 45: 1002-1009. DOI: 10.1111/j.1365-2664.2008.01491.x.

Krebs CJ. 1978. Ecological Methodology. Harper and Row Publisher, New York.

Krisanti AA, Choirunnafi A, Septiana NO, Pratama FW, Amelia F, Anjaswari A, Septiningtyas PA, Wati AS, Satria JY, Ani IL, Wibowo T, Sugiyarto. 2017. The diversity of diurnal bird species on western slope of Mount Lawu, Java, Indonesia. Biodiversitas 18 (3): 1077 1083. DOI: 10.13057/biodiv/d180327.

Kissling WD, Sekercioglu CH, Jetz W. 2012. Bird dietary guild richness across latitudes, environments and biogeographic regions. Glob Ecol Biogeogr 21: 328-340. DOI: 10.1111/j.1466-8238.2011.00679.x.

Kissinger, Pitri RMN, Violet. 2017. Vegetation and fauna diversity of high conservation value (HCV) swamp areas in oil palm plantations IOP Conf Ser: Earth Environ Sci 49: 012017. DOI: 10.1088/17551315/499/1/012017.

Kwatrina RT, Santosa Y, Sunkar A. 2019. The use of spatial analysis in confirming the environmental issue of oil palm and biodiversity. In International Conference on Biology and Applied Science (ICOBAS); AIP Conf Proc 2120: 040006. DOI: 10.1063/1.5115644.

Ludwig JA, Reynolds JF. 1988. Statistical Ecology: A Primer on Methods and Computing. John Wily and Sons, New York.

López-Ricaurtea L, Edwards DP, Romero-Rodriguez N, Gilroy JJ. 2017. Impacts of oil palm expansion on avian biodiversity in a neotropical natural savanna. Biol Conserv 213: 225-233. DOI 10.1016/j.biocon.2017.07.009.

Magurran AE. 2004. Measuring Biological Diversity. Blackwell Publishing, Oxford.

Mardiastuti A, Mulyani YA, Rinaldi D, Rumblat W, Dewi LK, Kaban A, Sastranegara H. 2014. Menentukan Kualitas Ruang Terbuka Kijau dengan Menggunakan Burung sebagai Indikator. Institut Pertanian Bogor, Bogor. [Indonesian]

Meijaard E, Sheil D. 2013. Oil-palm plantations in the context of biodiversity conservation. Encycl Biodivers 5: 600-612. DOI: 10.1016/B978-0-12-384719-5.00340-3.

Moudry V, Moudra L, Bartak V, Bejcek V, Gdulova K, Hendrychova M, Moravec D, Musil P, Rocchini D, Stastny K, Volf O, Salek M. 2021. The role of the vegetation structure, primary productivity and senescence derived from airborne LiDAR and hyperspectral data for birds diversity and rarity on a restored site. Landsc Urban Plan 210: 104064. DOI: 10.1016/j.landurbplan.2021.104064.

Ntongani WA, Andrew SM. 2013. Bird species composition and diversity in habitats with different disturbance histories at Kilombero Wetland, Tanzania. Open J Ecol 3 (7): 482-488. DOI: 10.4236/oje.2013.37056.

Obidzinski K, Andriani R, Komarudin H, Andrianto A. 2012. Environmental and social impacts of oil palm plantations and their implications for biofuel production in Indonesia. Ecol Soc 17 (1): 25. DOI: 10.5751/ES-04775-170125.

Santosa Y, Sugiharti W, Erniwati. 2018. The variation of bird diversity in different land cover at oil palm plantation: Case study at Asm Oil Palm Estate in Central Kalimantan, Indonesia. E3S Web Conf 52: 00051. DOI: $10.1051 / \mathrm{e} 3$ sconf/20185200051.

Simamoraa TI, Purbowo SD, Laumonier Y. 2021. Looking for indicator bird species in the context of forest fragmentation and isolation in West Kalimantan, Indonesia. Glob Ecol Conserv 27: e01610. DOI: 10.1016/j.gecco.2021.e01610.

Srinivas A, Koh LP. 2016. Oil palm expansion drives avifaunal decline in the Pucallpa Region of Peruvian Amazonia. Glob Ecol Conserv 7: 183-200. DOI: 10.1016/j.gecco.2016.06.005

Subasinghe K, Sumanapala AP. 2014. Biological and functional diversity of bird communities in natural and human-modified habitats in Northern Flank of Knuckles Mountain Forest Range, Sri Lanka. Biodiversitas 5 (2): 200-205. DOI: 10.13057/biodiv/d150212.

Subasinghe K, Sumanapala AP, Weerawardhena SR. 2014. The impact of forest conversion on bird communities in the northern flank of the Knuckles Mountain Forest Range, Sri Lanka. J Asia-Pacific Biodivers 7: 367-373. DOI: 10.1016/j.japb.2014.07.004.

Palomequea GR, Dupuya JM, Portillo-Quinterob CA, Andradea JL, TunDzula FJ, Hernández-Stefanonia JL. 2021. Mapping forest age and characterizing vegetation structure and species composition in tropical dry forests. Ecol Indic 120: 106955. DOI: 10.1016/j.ecolind.2020.106955.

Teuscher M, Vorlaufer M, Wollni M, Brose U, Mulyani Y, Clough Y. 2015. Trade-offs between bird diversity and abundance, yields and revenue in smallholder oil palm plantations in Sumatra, Indonesia. Biol Conserv 186: 306-318. DOI: 10.1016/j.biocon.2015.03.022.

Vijay V, Pimm SL, Jenkins CN, Smith SJ. 2016. The impacts of oil palm on recent deforestation and biodiversity loss. PLoS ONE 11 (7): 0159668. DOI:10.1371/journal.pone.0159668.

Yudea C, Santosa Y. 2019. How does oil palm plantation impact bird species diversity? A case study from PKWE Estate, West Kalimantan. IOP Conf Ser: Earth Environ Sci 336: 012026. DOI: 10.1088/1755$1315 / 336 / 1 / 012026$ 